\title{
Michele Ruth Gamburd.The Golden Wave: Culture and Politics after Sri Lanka's Tsunami Disaster. Bloomington: Indiana University Press, 2014. P. 217
}

\author{
Kalinga Tudor Silva \\ University of Peradeniya, Sri Lanka
}

This is a full scale ethnographic account of the impact of the tsunami disaster and the complex humanitarian response it gave rise to in a coastal community in south-westSri Lanka. The author introduces her study as "a political ethnography of a disaster" (Gamburd 2014: 1). In the social sciences, there is renewed interest in political ethnography, as a research method that involves closeup and real-time observation of actors involved in political processes, occasionally even extending the definition of these processes to move beyond categories of state, civil society, and social movements (Baiocchi and Cooner 2007). Set in Naeaegama (a rather cumbersomely spelt pseudonym meaning "village of kin"), where Michele first arrived in 1968 as the three-year old daughter of an anthropologist mother who undertook ethnographic research on kinship and caste in the first instance and which Michele revisited many times for her own research, focusing on diverse themes such as labour migration to the gulf region and male alcoholism (Gamburd 2000, 2008), the study under review is more like a conventional ethnography of a bounded village community, but perhaps it qualifies as a political ethnography in the sense that political dynamics and governance issues relating to the massive humanitarian response to the tsunami disaster in Sri Lanka forms an important theme of the study. As an ethnographer, the researcher has been able to monitor developments in this village over a long period of time and her tsunami research essentially builds on her prior understanding of the demography, social relations, politics and cultural dynamics of the village.

Further, the work under review builds on and contributes to the vast body of literature on the social and developmental impact of tsunami in Sri Lanka consisting of several edited volumes (e.g. de Mel, Ruwanpura and Samarasinghe 2009, McGilvray and Gamburd 2010 ), monographs (e.g. Moonasinghe 2007 ) and articles in academic journals (e.g. Stirrat 2006, Silva 2009) and a multitude of reports by government and non-government organizations (e.g. 
RADA 2006,Gomez \& Mylavaganam 2005 ). The heightened anthropological gaze on the tsunami disaster is understandable given the global concern over disasters in recent decades, the widespread global media coverage that the tsunami disaster of December 2004 attracted in this globalized era of instant information flows and the massive influx" of aid that immediately followed. One of the unique features of Gamburd's study is that it monitored tsunami experience and response in the selected site over a five year period from 2004 to 2009 covering the process of transition from relief to resettlement and recovery, paying attention to intervening issues, including charitable activities on the part of local communities, aid flows, official demarcation and redemarcation of the buffer zone, large-scale displacement of people, and intense competition for control over land and aid flows in the aftermath of the disaster. Thus Gamburd provides a longer term perspective and an emic view of the tsunami-affected people that are missing in many of the previous studies.

The book is organized around the sequence of events from the onset of the disaster. The introduction titled "Political Ethnography of Disaster" introduces the larger context of the Indian Ocean Tsunami, the setting of Naeaegama village and themes explored in the study. Chapter One titled "That Day: Chaos and Solidarity" explores the memory of the tsunami disaster from the angle of the community members who lost two lives and many of their houses and belongings during the disaster? The author's visit to the community in early 2005 enabled her to explore people's memories still fresh in their minds in spite of the rapid changes and movements they experienced from the time of the onset of the disaster. The focus of Chapter Two is on how people made sense of the disaster as it happened to them personally, their family members and the community at large also invoking Buddhist ideas such as karmic retribution. Chapter Three investigates the life in "Short-term Camps" established mostly in local Buddhist temples with support and charitable contributions of local community members and shop owners. In many instances this period was limited to one or two weeks during which the process of relief services was largely under the control of local communities. Chapter Four deals with the issue of housing where complex problems such as the scarcity of land, changing state policies relating to the buffer zone and the government inaction and delay in locating suitable land outside the buffer zone prevented the rapid rebuilding of damaged or destroyed houses or construction of 
alternative housing for those in temporary shelter. Chapters Five to Nine bring out various aspects of post-tsunami humanitarian aid flows including the role of local mediators, corruption, poor targeting, misappropriation and misuse of relief also involving cheating and the interethnic competition for control and distribution of aid in the country at large. Each chapter is followed by the story line relating to a particular individual who illustrates some of the key points made in the relevant chapter. This is a useful narrative devise that adds to the readability of the text and enables the reader to connect biography with larger social and political processes operating at various levels. Finally, the conclusion returns to the theme of "the Golden Wave" identified and developed as the overall theme of the book.

The idea of "the golden wave" (rattaran ralla), captured in the title of the book, is a reportedly widespread view held by the rural elite that the tsunami was a blessing in disguise for the poorer people in the area while it served to destroy the assets and property owned by the elite. In this view the aid flows enabled the poorer people to improve their housing and asset ownership, liberally taking advantage of, and using and abusing services of the state and NGOs and the goodwill of local and foreign philanthropists. This idea is also invoked by the elite to resent what they see as the levelling effect of tsunami and the aid flows that followed as graphically captured in the following expression:

The person who had (assets), lost

The person who didn't have, gained

[Aeti miniha naeti unaa

Naeti minha aeti una]

(Gamburd 2014: 149) (The word "assets" not in the original)

According to Gamburd, the golden wave discourse was put forward by the rural middle class to stress that they lost their privileged position in society as a combined outcome of tsunami and tsunami response, that they do not want to tap into the aid flow the way poorer people did due to their status considerations, personal integrity and reluctance to misuse aid, and, thereby assert their social and moral superiority over the aid dependents. While the author presents this as an elite discourse rather than a statement of facts, a more critical take on this discourse is warranted on a number of counts. First of all, given the role of some members of the local elite as mediators in aid flows and some accusation of corruption against them one could certainly question the views that 
they have not befitted from the golden wave and that they have not tapped into the aid flows. Secondly, some of the state policies seem to encourage transfer of land from tsunami victims to local entrepreneurs including tourist businesses as the author herself clearly recognizes. Thirdly, the degree of upward social mobility experienced by the ultra-poor cannot be over exaggerated due to the poor quality of new housing they have received, poor infrastructure in the housing schemes, the dependency mentality the aid flow has givent rise to and their unwillingness to work hard in the light of assistance received, as indeed recorded in detail by the author. Fourthly, the idea of the golden wave completely ignores the massive suffering that the more vulnerable people experienced in terms of human loss, displacement, loss of livelihoods and poor living conditions in temporary shelter in particular. Finally, contrary to the cultural logic implicit in the idea of a golden wave, in colloquial Sinhala the new word "sunami" refers to an explosive and, at the same time, puzzling new development that is potentially threatening as in "sumani sunami masso" (tsumai flies) referring to a new pest of domestic flies and "sunami machine", universally referring to the labour displacing combine harvester widely employed in harvesting of paddy in the Dry Zone Sri Lanka. While it is true that tsunami relief was perhaps a blessing in disguise for some people, it only captures a part of the story and certainly not the total or even the central core of post-tsunami experience of residents of the south-western coastal belt.

The study carefully documents the down-stream problems and distortions in tsunami aid distribution also taking into account the cultural and political logic that seem to guide this process. While this is indeed useful, what is missing is a macro level analysis of structural problems in humanitarian aid flows and development programmes that in turn influence down-stream processes and practices (Stirrat 2006, Kennedy 2005). While the methodological limitations of political ethnography may be relevant here, it is nevertheless important to recognize that there are structural impediments associated with global aid flows as is well documented in the literature.

Quoting previous literature, the study states that the coastal buffer zone tends to relieve land previously owned by tsunami victims for tourism development on the part of local and outside entrepreneurs. 
"The one-hundred-meter buffer zone was a major issue that presented a series of concerns. Individuals and government officials weighed choices and made trade-offs between the risk of future tsunami, the difficulty of finding land for new houses, and the need to provide quick and easy access for fishermen to the sea. Whether by chance or design, the timing and particulars of the buffer zone policy changes facilitated the sale of valuable beachfront property from displaced residents to wealthy individuals and corporate buyers....... The results raise questions of social justice and disaster capitalism" (Gamburd 2014: 90)

While the study location and the longer time perspective taken by this study provide a useful setting to empirically examine if this process has indeed taken place in the study area well-established as a popular tourist resort where tourism bounced back after the setback and major disruption caused by tsunami, the author does not explore this issue.

From a developmental point of view, the study site and the longer time frame of the study provided an ideal opportunity to explore who achieved satisfactory recovery over this period and who did not and for what reasons. The author has opted to not investigate this issue at all and this too may be seen as a missed opportunity. As often happens, the discourse analysis pursued in the study has had the effect of making it difficult to identify and understand any social and economic reality beyond discourses.

The ethnographic strategy employed in this study relies on a limited circle of contacts built around Siri, identified as the research associate, long standing friend and the host who contacts other informants, translates and interprets for the benefit of the ethnographer. The ethnographer visited and interviewed the same network of informants time and again in order to follow up developments since the previous visit. While the ethnographer appears to be well aware of the strengths and weaknesses of the particular research network, she does not systematically explore any alternative sources of information such as detailed observation, secondary data in government and NGO circles, key informant interviews with a wider cross section of actors and activists and group discussions with diverse stakeholders such as women, children and youth. 
These limitations, however, do not take away from the value of this study as a useful contribution to the growing anthropological literature on disasters and Sri Lanka society in general.

\section{References}

Baiocchi, Gianpaolo and Connor, Brian T.The Ethnos in the Polis: Political Ethnography as a Mode of Inquiry. Sociology Compass, 2/1 (2008): 139-155.

De Mel, N., Ruwanpura, K. \& Samarasinghe, G. eds.After the Waves: the Impact of Tsunami on Women in Sri Lanka. Colombo: Social Scientists Association,2009

Gamburd, Michele Ruth.The Kitchen Spoon's Handle: Transnationalism and Sri Lanka's Migrant Housemaids. Ithaca: Cornel University Press, 2000.

---Breaking the Ashes: the Culture of Illicit Liquor in Sri Lanka.Ithaca: Cornel University Press, 2008.

---.The Golden Wave: Culture and Politics after Sri Lanka's Tsunami Disaster. Bloomington: Indiana University Press, 2014.

Gomez, Shehanna \& Mylavaganam, Shalindra. Consultation on Children Post-tsunami: Legal and Policy Issues. Colombo: Centre for Policy Alternatives, 2005.

Kennedy, David.The Dark Sides of Virtue: Reassessing International Humanitarianism. Princeton: Princeton University Press, 2005.

McGilvray, D. \& Gamburd, M.R. eds.Tsunami Recovery in Sri Lanka: Ethnic and Regional Dimensions. London: Routledge, 2010.

Moonesinghe, S.Politics, Power Dynamics and Disaster: A Sri Lanka Study on Tsunami-Affected Regions. Colombo: International Centre for Ethnic Studies, 2007.

Reconstruction and Development Agency (RADA)Mid-Year Review: Post-Tsunami Reconstruction and Recovery. Colombo: RADA, 2006.

Silva, K.T.'Tsunami Third Wave' and the Politics of Disaster Management in Sri Lanka." Norwegian Journal of Geography 63 (1): 61-72, 2009

Stirrat, Jock. "Comparative Humanitarianism: Relief and the Tsunami in Sri Lanka."Anthropology Today 22 (5): 11-1,20 